\title{
Bertel Petersen Godt Slesvigs biskop 1864-1885
}

Belyst udfra nogle visitatsberetninger

Af Asger Nyholm.

Bertel Godt (f. 1814) var landmandssøn fra Rinkenæs. Han modtog, hedder det, troen som en arv fra hjemmet. ${ }^{1}$

Han kom i latinskolen i Flensborg, hvis rektor var den lærde klassiker, æresdoktor ved Kiels Universitet, Friedr. Carl Wolff."

I 1834 blev Godt indtegnet som teologisk student i Kiel. Efter gældende bestemmelse skulle man have studeret to år $\mathrm{i}$ Kiel for at få embede $i$ hertugdømmerne.

Ved århundredskiftet havde rationalismen været næsten eneherskende i Kiel, både blandt borgerskabet og ved universitetet. Men netop da var det blevet klart for mange $i$ den unge generation, at rationalismen havde overlevet sig selv. Teologien tog en ny retning, som så mange steder i Tyskland, under indtryk af romantikken og frihedskrigen mod Napoleon.

Der udgik allerede før år 1800 stærke pietistisk-herrnhutiske impulser fra den kreds, der samledes om grev Fritz Reventlow og hans fromme hustru, Julia Reventlow (f. Schimmelmann) på godset Emkendorff. Som kurator for universitetet havde Reventlow prøvet at modarbejde rationalismen dér. Til Emkendorffkredsen hørte bl. a. digteren Matthias Claudius, der gennem sit blad \& Wandsbecker Bote på uprætentiøs måde og med en egen varm humor øvede sund indflydelse på fromhedslivet $\mathbf{i}$ hertugdømmerne.

I Berlin bragte Tysklands store teolog, Fr. Schleiermacher, teologien til ny ære og værdighed med sine "Taler om religionen til de dannede blandt dens foragtere". Han fremstillede religionen som den højeste livsværdi og den højeste kulturudfoldelse, som 
sind og sans for det uendelige, som noget langt højere end sund fornuft og anstændig moral, hvad rationalismen — dens gode sider ufortalt - efterhånden havde reduceret religionen til.

Kiels Universitet fik en repræsentant for denne nye teologiske retning, da den 25-årige teolog August Twesten ${ }^{3}$ i 1814 blev ansat som professor. Han var elev af og ven med Schleiermacher og blev derfor modtaget med megen skepsis af sine ældre teologiske kolleger, der var af rationalistisk skole. Men han sluttede sig derimod nært til den kreds af andre, tildels jævnaldrende professorer, der begyndte at udgive "Kieler Blätter" $\mathbf{i}$ "det uforglemmelige år 1815, da Tyskland igen vandt sin politiske frihed gennem de tre foregående års tunge ofre". Til denne kreds hørte juristen Niels Falck og historikeren Dahlmann, endvidere juristen Welcker, medicinerne C. H. Pfaff, Chr. Wiedemann og Franz Hegewisch samt teologen Kleuker. ${ }^{4}$

Det var den gængse tro i tiden, at retfærdigheden på jorden og sandheden om det evige var noget, som alle mennesker til alle tider kunne filosofere sig til. Man fandt det i den unge generation lidt for luftigt således at ville hente sandheden ned "fra skyerne". Man fandt det nødvendigt i stedet at bygge på den virkelighed, der gennem fortiden var blevet til som »arven fra fædrene". Man studerede derfor flittigt historien og fandt tilbage til de gamle skrevne vedtægter, som nutiden måtte bygge videre på. Politisk fandt man grundlaget for hertugdømmernes indbyrdes forhold $i$ »Ribebrevet « af 1460 med de berømte ord, at Slesvig og Holsten skal blive "ewich tosammende ungedelt ". Det blev den senere Slesvig-Holstenismes bekendelsesskrift. På tilsvarende måde fandt man kirkeligt tilbage til den slesvig-holstenske kirkes bekendelsesskrifter, »den Augsburgske trosbekendelse" af 1530 og »Konkordiebogen " af 1580, hvori de gamle lutherske teologer havde trukket grænserne klart op imod katolicisme, calvinisme og andre vranglærdomme. Den rene lutherske lære, som de var udtryk for, havde rationalismens præster sagt sig løs fra. Men en ny tids bekendelsestro kirkelighed begyndte nu at holde præsterne lige så fast på kirkens bekendelsesskrifter, som Slesvig-Holstenismen stod fast på Ribebrevets "ewich tosammende ungedelt «. Således fik på ejendommelig måde Slesvig-Holstenismen og en bekendelsestro kirkelig bevægelse fælles udspring. I »Kieler Blät- 
ter" skrev Niels Falck, at det var lige så vigtigt for teologerne at studere bekendelsesskrifterne som at studere bibelen. Og Twesten formulerede sætningen: "Wer die Religiosität der Väter will, muss auch die Religion der Väter wollen ".

Sammenlignet med indflydelsen fra grevehoffet på Emkendorff, fra Schleiermachers taler til de dannede og fra de fra universitetskredse udgåede » Kieler Blätter" nåede indflydelsen fra Claus Harms langt videre.

Claus Harms var møllersøn fra Ditmarsken. Han bevarede hele sit liv et dybt indtryk af forældrenes fromhed. Han glemte aldrig den stille højtid, der var i hjemmet, når forældrene om søndagen vendte hjem fra altergangen i kirken. ${ }^{5}$ Han gjorde Twestens ord om fædrenes "Religiosität « til sine.

Claus $\mathrm{Harms}^{6}$ havde under indtryk af romantikken og af Schleiermacher vendt sig helt fra rationalismen. Efter ti års præstetid i Lunden blev han i 1816 præst ved Nicolai kirke i Kiel. Det skyldtes ikke mindst indflydelse fra universitetskredse, at han fik dette embede. Allerede $i 1817$ vakte han opsigt $i$ vide kredse, idet han $i$ anledning af reformationsjubilæet udsendte 95 theser - et supplement til Luthers 95 theser fra 1517 - hvori han rettede et voldsomt angreb på rationalismen. Disse theser bidrog stærkt til at drage sindene bort fra rationalismen. Men iøvrigt fik han meget stor indflydelse på kirkelivet i hertugdømmerne. Han samlede søndag efter søndag en stor skare om sin prædikestol - endogså den inkarnerede rationalistiske professor Eckermann hørte ham. Han udgav ialt 356 trykte prædikener, der blev flittigt læst rundt i hertugdømmerne, og som endnu kan fængsle læseren ved deres djærve og folkelige stil. Det er næppe for meget sagt, at Harms kom til at præge et par generationer af hertugdømmernes gejstlighed. Teologerne strømmede til kirke hos ham. Han samlede dem i sit hjem og gennemgik med dem præstegerningens mange problemer. Hans samtaler med dem ligger til grund for hans meget læste "Pastoralteologi" .

Således havde stærke impulser skabt et nyt klima i den teologiske verden. Begejstret skildres studietiden for teologerne $i$ disse ártier som en forårstid: Schleiermacher, en af teologiens største mestre, havde anvist videnskaben om fromheden og troen sin værdige plads blandt de andre videnskaber; Harms, den dyrebare 
»Gottesmann «, forkyndte bekendelsen, så studenterne blev opfyldt af begejstring for deres fremtidige kald. ${ }^{7}$

Det var dette teologiske klima, som Godt mødte, da han kom til Kiel i 1834. Den gamle rationalisme var da kun repræsenteret af to professorer, den 80-årige sprænglærde sprogmand, J. C. R. Eckermann og den 71-årige Georg Samuel Francke. ${ }^{8}$ Nu var Twesten det store navn ved fakultetet. Imidlertid overtog Twesten efter Schleiermachers død i 1835 dennes lærestol i Berlin. Det er formodentlig derfor, at Godt en tid studerede i Berlin, hvor han samtidig fik lejlighed til at høre kirkehistorikeren Aug. Neander, hvis inderlige og ægte fromhed kommer til udtryk $i$ hans yndlingssentens: det er hjertet, der skaber teologen.

Nye lærerkræfter blev iøvrigt mere eller mindre nært knyttet til Kiels Universitet i disse år: Chr. N. T. H. Thomsen, der betragtede Schleiermacher som den store teologiske og kirkelige reformator, C. P. Lüdemann, der stod Claus Harms så nær, at han siden blev hans skriftefader, H. A. Mau, medlem af bestyrelsen for GustavAdolf-foreningen, og A. F. L. Pelt, der blev Twestens efterfølger. Politisk kom disse til at følge den slesvig-holstenske kurs - Pelt blev afskediget af den danske regering i 1852."

Det er ikke opgaven her - hvis det i det hele lader sig gøre at udrede de enkelte læreres betydning for Godt. Han har med åbent sind levet sig ind $\mathbf{i}$ den teologiske verden, han mødte. Han var i 1836 med til at stifte en teologisk forening, hvor studenterne - dog ikke over 16, for at sikre alle medlemmernes aktive deltagelse - ugentlig samledes for at drøfte og uddybe det stof, deres professorer havde gennemgået. ${ }^{10}$

Det ser ud til, at Claus Harms har haft en afgørende betydning for Godt. Det vil fremgå af det følgende, at Godt i mangt og meget deler Harms' teologiske syn, specielt hans kirkesyn, som det i Harms' folkelige læsebog, „Gnomon «, er udtrykt i to jævne sætninger: den, der ikke deler kirkens tro, hører ikke til kirken, og: den, der ikke har kirken til moder, kan ikke have Gud til fader. ${ }^{11}$ Harms kan ikke på det tidspunkt have påvirket Godt i slesvig-holstensk retning. Harms var dengang kongetro helstatsmand, der gav Frederik 6. det vidnesbyrd: "Dänen und deutsche waren seine Kinder beyde, er unser beyder Vater. Zwei Kammern 
Ein Herz, zwey Völker Eine Liebe « ${ }^{18}$ Først sent og modstræbende gav Harms Slesvig-Holstenismen sin tilslutning. ${ }^{13}$

1839 tog Godt teologisk embedseksamen. Han var en tid huslærer i Augustenborg og blev gift med en datter af Joachim Petersen, fyrstelig hofråd hos hertugen, Chr. August af Augustenborg. I. tre år var han derefter præst $i$ sit fødesogn, Rinkenæs. Så blev han af hertugen af Augustenborg kaldet til præsteembedet i Notmark på Als, og fra 1846 var han præst i Felsted.

Så kom de urolige år 1848-50. Gejstligheden i hertugdømmerne var gennemgående præget af den slesvig-holstenske atmosfære, de havde mødt $i$ deres studieår $i$ Kiel. Mange af dem erklærede sig åbenlyst for det slesvig-holstenske statholderskab som landets lovlige øvrighed, og mange af dem måtte bøde derfor efter krigen. De blev under megen bitterhed fjernet fra deres embeder. Godt havde også åbenlyst vist slesvig-holstensk indstilling. Man ønskede dog fra dansk side ikke at se ham fjernet fra Slesvig, men tilbød ham forfremmelse til stillingen som provst i Husum. Han afslog det imidlertid og var derefter i tiden mellem krigene, indtil 1864 , præst i egnen omkring Ruhr.

I begyndelsen af 1864 vendte han tilbage og stillede sig til rådighed for den preussiske civilforvaltning, der skulle styre Slesvig, efterhånden som erobringen skred frem. Han blev 9. april, altså kort før slaget ved Dybbøl, præst i Grumtoft i Angel, derefter i Broager og samtidig provst for Åbenrå-Sønderborg provsti. Han havde som provst nogle skarpe sammenstød med præsterne og den danske befolkning på nogle visitatser, bl. a. i sit gamle sogn, Felsted, hvor Mørk Hansen var præst. ${ }^{14}$

Den 13. juli - altså et par uger efter preussernes overgang til Als - holdt Godt i Slesvig en prædiken ved genoprettelsen af den slesvig-holstenske Gustav-Adolf-forening.

Gustav-Adolf-foreningen ${ }^{15}$ var oprettet i 1842 i Leipzig som en forening af evangelisk-protestantiske kristne til stotte for betrængte trosfæller i katolske lande. Det lyder upolitisk. Men den afdeling af foreningen, der blev stiftel for Slesvig-Holsten-Lauenborg i Kiel 1842, blev båret frem af slesvig-holstensksindede gejstlige, der $\mathbf{i}$ foreningen også så et middel til at knytte Slesvig og Holsten sammen. På grund af foreningens udpreget slesvigholstenske farve var den under det danske styre i Slesvig mellem 
krigene afskåret fra at virke i Slesvig. Det var altså en politisk demonstration, at man nu, midt under krigen, genoprettede foreningen som en slesvig-holstensk forening.

I denne prædiken ${ }^{18}$ gav Godt stærkt udtryk for bitterheden hos de præster, der var blevet fordrevet efter treårskrigen. Særlig angreb han - som det var almindeligt fra den kant - det danske sprogstyre, de såkaldte sprogreskripter. Ved disse havde man i 1851 indført tvungent dansk skole- og konfirmationssprog og skiftende dansk og tysk kirkesprog i ca. 50 sogne i Mellemslesvig, som lige siden reformationstiden udelukkende havde haft tysk sprog i kirke og skole, skønt folkesproget var sønderjysk. Videre angreb han det danske styre, fordi det end ikke havde været muligt at holde en fælles forsamling for Gustav-Adolf-foreningen i Slesvig og Holsten. Så bange var man for ethvert fællesskab mellem de to hertugdømmer, så afhængig var religionen af politik og kirken af staten. $\mathrm{Nu}$ var imidlertid hjælpen kommet sydfra, så man turde have fuld fortrøstning til, at hvad Gud har sammenføjet, ikke kan skilles af mennesker: Slesvig og Holsten skulle ingensinde skilles.

1. august 1864 blev Godt biskop - "generalsuperintendent " for Slesvigs bispedømme. Den 30. oktober blev freden undertegnet $\mathrm{i}$ Wien, hvorved begge hertugdømmer blev afstået til Preussen og Østrig. Biskoppen udsendte derefter på Martin Luthers dag, den 10. november, til stiftets præster og menigheder en rundskrivelse, der gjorde ham berygtet $\mathrm{i}$ dansksindede kredse. I denne skrivels $^{17}$ forordner han en fredsfest $i$ hertugdømmernes kirker på 2. søndag i advent, fordi "den for vort lands ret førte krig er lykkelig endt ", og fordi der er opnået en fred, "der må opfylde os med levende glæde ".

Slesvig-holsteneren havde talt. Godt følte sig stående ved det mål, han havde set hen til: at viderefore den kirkelige udvikling i 'Twestens og Claus Harms' ånd, som han havde set afbrudt af et forsøg på at bringe udviklingen ind $i$ danske - tildels grundtvigske - baner.

Men landets skæbne var ikke afgjort. Man mærker i nogle af de prædikener, som præsterne holdt ved takkegudstjenesterne 2. søndag i advent - flere af dem er trykt -- ængstelsen for lan- 


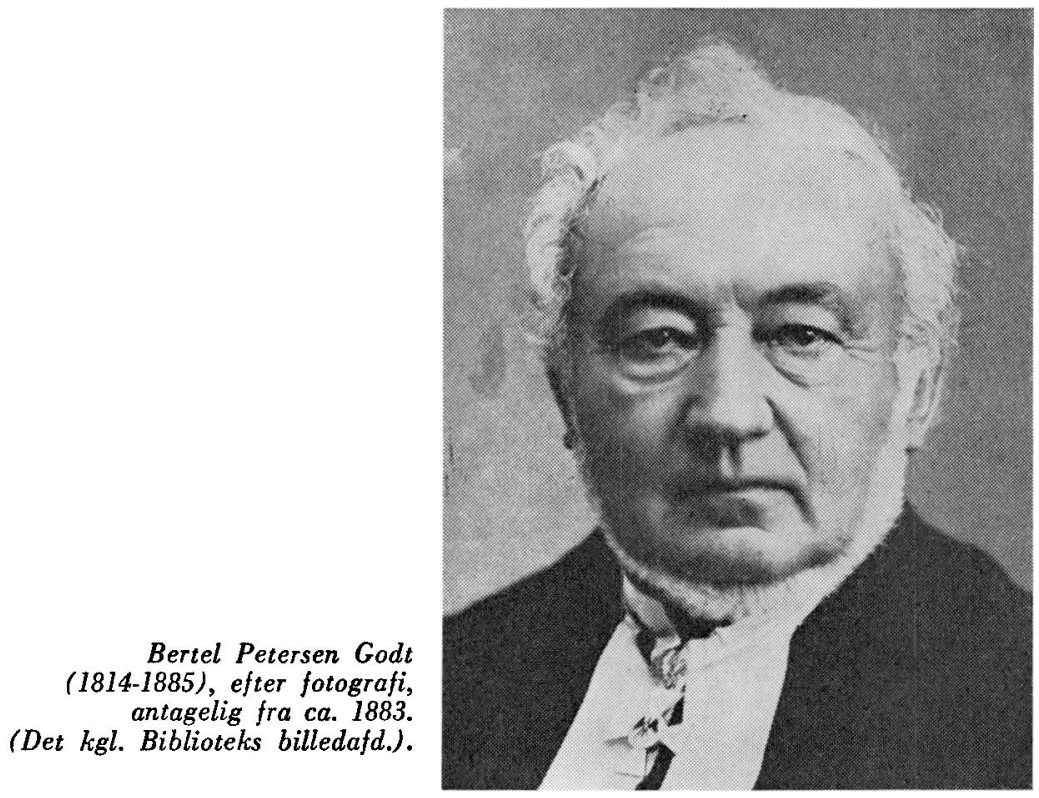

dets fremtid. Engstelsen var ikke ubegrundet. Slesvig-holstenerne havde drømt om et selvstændigt Slesvig-Holsten under hertugen af Augustenborg, "den angestammten Herzog ". Denne drøm gik ikke i opfyldelse. Efter krigen mellem Preussen og Østrig i 1866 blev begge hertugdømmer i januar 1867 indlemmet i Preussen.

Den slesvig-holstenske gejstlighed led svære samvittighedskvaler. Man havde i stærke udtryk erklæret det for en samvittighedssag at vise troskab mod hertugens guddommelige ret - og nu skulle man aflægge troskabsed til kongen af Preussen.

Hvordan stillede Godt sig til dette? Han havde jo fra tidligere tid en vis tilknytning til augustenborgeren. Måske finder man en antydning derom i en tale, som provst Ziese i Slesvig holdt ved hans begravelse. ${ }^{18}$ Han fortæller der, at Godt var betænkelig ved meget af det, der skete på politisk og kirkeligt område. Men han erkendte deri nødvendighedens jernhårde gang, som man må bøje sig under, og han fandt deri den Guds tanker, som også har det i sin hånd, der byder én imod, for at føre dette til en god udgang.

Var det indlemmelsen i Preussen, der bød slesvig-holsteneren 
imod, som tilfældet var med så mange? Det er vel ikke usandsynligt, at det er dette, provst Ziese sigter til.

Det er klart, at det var en vanskelig post, Godt overtog som biskop. Kirkelivet i Slesvig havde lidt meget under de politiske forstyrrelser og særlig ved de to krige. Efter krigen 1848-50 havde den danske regering fjernet mange af de gejstlige fra deres embeder på grund af deres slesvig-holstenske holdning. Efter biskop Martensens mening hørte den ædleste del af den slesvigske gejstlighed til de fordrevne. ${ }^{10}$ En række dansksindede præster nordfra blev indsat i deres sted. Men efter krigen 1864 måtte de på deres side fortrække (gradvist 1864-67, da de nægtede at aflægge ed overfor det nye styre, og yderligere 1870, da de nægtede at bede for Tysklands sejr). Det var præster, som provst H. P. Prahl i Haderslev har betegnet som dygtige præster på deres måde. ${ }^{20}$

Nu skulle kirken konsolideres under et styre, der bød de dansksindede imod, og som ikke var det, som de slesvig-holstensksindede havde onsket.

Det historiske problem er, om biskoppen mest følte sig stående i statens eller i kirkens tjeneste, om han virkede mest for den tyske sag eller for kirkens sag, om - som det er sagt ${ }^{21}$ - det nationale kom til at dominere det kristelige.

Skal man besvare dette spørgsmål, må man kende biskoppens teologiske såvel som hans politiske standpunkt. I det følgende skal hans teologiske indstilling søges belyst udfra en del af hans visitatsberetninger. Om det politiske indeholder disse meget lidt.

Det var ved gamle bestemmelser fra Christian 6.s tid"9 pålagt biskoppen at holde sgeneralvisitationer", d.v. s. at besøge hvert af stiftets sogne hvert tredje år. Han skulle give indberetninger om præster og menigheder til den øverste kirkestyrelse, overkonsistoriet i Kiel.

Disse visitatsrejser var anstrengende. Når biskoppen kom til den pågældende præstegård om aftenen, skulle der på hans værelse forefindes de dåbs-, vielses- og dødsregistre samt andre bøger, som det var præstens pligt at føre. Endvidere forlangte han indberetninger fra sognets lærere om, hvad der $\mathbf{i}$ de sidste tre år 
var gennemgået $\mathrm{i}$ religionstimerne. $\mathrm{Og}$ endelig skulle der fra præsten foreligge en udførlig indberetning med besvarelse af en række spørgsmål, som biskoppen forud havde sendt til ham: om kirkebesøget, antal af nadvergæster, om kirkekatekisationerne, ${ }^{23}$ om der var interesse for missionen, Gustav-Adolf-foreningen eller andre kirkelige formål. Endvidere om fromhedslivet i sognet: om der holdtes husandagt i hjemmene eller bordbøn, om der blev holdt konventikler eller fandtes sekter. Også om det sædelige liv i sognet skulle præsten give oplysninger: om antallet af fødsler udenfor ægteskab, om skoleungdommens opførsel, om overholdelse af sabbaten. Endelig skulle præsten give oplysning om skolevæsenet, om fattigvæsenet og om bygningernes vedligeholdelse.

På selve visitatsdagen blev der først holdt gudstjeneste. Den var forud bekendtgjort, for at menigheden kunne være tilstede. Også konfirmanderne fra de tre sidste år - altså siden sidste visitats skulle give møde. Præsten holdt en forholdsvis kort prædiken. Derefter skulle han katekisere med konfirmanderne. Det var en ret krævende undervisningsform, som imidlertid drevet med dygtighed appellerede både til børnenes viden og tænkeevne. Efter præsten overtog biskoppen selv katekisationen - Godt skal have gjort det aldeles ypperligt. Endelig tilsidst holdt biskoppen en tale til menigheden, opfordrede den til kirkeligt liv og kirkelig bevidsthed og gav eventuelt menigheden nogle særlige formaninger, hvor der kunne være anledning dertil. Nogle steder formanede han til at genoplive de efterhånden noget sjældne skikke med husandagt og bordbøn. I Morsum på Sild advarede han mod de mange dansegilder. I Branderup, hvor man mente, at der i grundtvigske kredse ovedes for lidt tugt overfor børnene, formanede han både forældre og lærere i så henseende.

Siden besøgte biskoppen skolen, hvor sognets børn blev overhørt $\mathbf{i}$ de forskellige fag - ydelserne i sang, skriver Godt meget åbenhjertigt, kunne han ikke bedømme, men nogle steder var de dog så mådelige, at det endog sårede hans øre.

Endelig tilsidst mødtes biskoppen med sognets lærere, menighedens repræsentanter (de såkaldte kirkeældste), samt sogne-, skole- og fattigforstandere for at høre, om de havde nogle ønsker eller klager at fremføre.

Ved fire-tiden kunne visitatsen gerne regnes for afsluttet, og 
sognet skulle så stille to heste til hans videre befordring til næste sogn, hvor han skulle visitere næste dag.

Godt var en meget flittig visitator. Trods store personlige sorger - han mistede sin hustru, to døtre og to sønner -, og skønt han tilsidst var så afkræftet, at en anden måtte føre visitatsprotokollen for ham, fortsatte han trofast sine anstrengende visitatsrejser med stor udholdenhed.

Under visitatsen gjorde Godt meget grundige notater i sin visitatsprotokol. På grundlag af disse notater udarbejdede han sine indberetninger til konsistoriet. Notater og protokol svarer stort set til hinanden. De er meget udførlige og rummer et væld af oplysninger.

Det er disse protokoller og indberetninger, der er lagt til grund for den følgende fremstilling. Det drejer sig kun om visitatser i Nordslesvig samt nogle sogne i Sydtønder amt, der dengang hørte til Tønder provsti.

Godt skal have stået på en god fod med befolkningen, der satte pris på, at han kunne tale med dem i deres eget sønderjyske mål. Han var jævn og bramfri i sin optræden. ${ }^{24}$ Han advarede sine præster mod hierarkisk væsen og var selv ikke altfor ivrig med at hævde sin embedsmyndighed. Det hændte, at de sidste tre års konfirmander langtfra alle mødte til visitatsen, som de skulle. Men Godt ville ikke - som sin forgænger, biskop Boesen, prøve at bruge tvang, men søgte blot hos menigheden at vække bevidstheden om det gode i denne gamle skik. ${ }^{25}$

Gennemgående mødte menighederne godt frem til visitatsgudstjenesterne, i adskillige dansksindede sogne endda talrigt, så kirken var "gedrängt voll «. Agitation for at udvirke demonstrativ udeblivelse omtales kun få steder. I Mjolden, hvor Hans Sveistrup (om ham: se senere) holdt danske møder, forlød det, at man på foranledning udefra havde aftalt at holde sig borte (1871). I Møgeltønder mente Godt, at redaktøren af "Vestslesvigsk Tidende" (redaktør Willemoes, der udgav bladet i Møgeltønder) og nogle andre dansksindede partiførere havde virket stærkt mod deltagelse (1871). Ved visitatsen $1868 \mathrm{i}$ hans gamle sogn, Felsted, var kirken fyldt, skønt hans danske forgænger, Mørk Hansen, 
under et tre dages ophold i sognet umiddelbart før havde søgt at påvirke befolkningen til at holde sig borte.

Præsterne forstod Godt at bedømme. Hvis der står om en præst, at han er afholdt i sin menighed, skal man se nøje efter, om der også står, at han fortjener det. Den skarpsynede biskop lod sig ikke imponere af en præsts popularitet. I 1873 visiterer han hos en præst, der bliver anset for at være en betydelig prædikant, også uden for sin egen menighed. Det kan biskoppen kun forklare sig ved, at han taler med friskhed og varme, for Godt synes, at han er uklar, et ulogisk hoved og en middelmådig teolog. I 1879 står samme præst sønderknust overfor biskoppens berettigede kritik af hans meget ringe prædiken og må indrømme, at noget alvorligt hviler på ham som et band. Hvad det drejer sig om, bliver foreløbig min hemmelighed, skriver Godt. 1880 blev præsten afskediget.

Godts karakteristikker af præsterne er meget levende. Han spiller på hele karakterskalaen og bider sig ikke fast i stereotype udtryk.

En af de præster, han omtaler i de mest rosende udtryk, er Niels Schmidt i Svenstrup, forstander for Tønders tvesprogede seminarium fra 1864 til 1870 , da han tog sin afsked, fordi han som slesviger var misfornøjet med det preussiske styres indgriben i seminariets ledelse. ${ }^{26}$ (Schmidt var fader til det tyske mindretals repræsentant i Folketinget $\mathrm{i}$ tiden mellem de to verdenskrige, pastor Schmidt, Vodder). Godt skriver ved visitatsen i 1872, at Schmidt med stor varme og liv holdt en prædiken, der vidnede om alvorligt og indtrængende skriftstudium, var meget godt disponeret og udarbejdet, sandt opbyggende og mægtigt gribende. Og han fortsætter: Schmidt hører afgjort til de mest begavede og betydelige præster i hertugdømmet. Han tænker klart og skarpt og føler dybt og inderligt. Han er en sjældent fortræffelig karakter og en yderst elskelig personlighed. Hans hele embedsførelse tør kaldes mønsterværdig og rigt velsignet, og han kan glæde sig ved agtelse og tillid i rigt mål, ikke blot $i$ sin menighed og blandt sine nærmeste kolleger, men i vide kredse.

Adskillige dygtige præster får deres velfortjente ros. Om en prædiken hedder det, at den var godt udarbejdet, af sandt evangelisk indhold, fuld af hellig alvor og »werbende Liebe«. Om en 
anden prædiken siges, at den var teksttro, ud af skrift og erfaring, for troen og for livet, levende og inderligt holdt (A. D. Grauer og J. J. A. Momsen, begge i Burkal, henholdsvis 1869 og 1881).

Godt var noget kritisk overfor pietisme. Emil Wacker $\mathrm{i}$ hans fødesogn Rinkenæs, den senere forstander for Diakonissestiftelsen i Flensborg, var i hans øjne vel en højt begavet prædikant og en ivrig sjælesørger, men Godt fandt ham undertiden for "stürmisch ", så han stødte nogle bort. Alligevel anerkendte Godt uforbeholdent dygtigt arbejde af pietistiske præster. Han skriver om Nic. C. Nielsen ${ }^{27}$ i Højrup, at man i hans prædiken »fühlte das Werben um die Seelen" (1876), eller senere, at hans prædiken var ret en prædiken for en landmenighed, meget fængslende, gribende og opbyggelig (1879).

Prædikenernes mangler forties ikke. Hos en iøvrigt dygtig præst af Schleiermachers skole finder Godt for megen tiltro til menighedens moralske højnelse og for lidt betoning af boden, troen og omvendelsen (Gerber i Klægsbøl). En prædiken forekommer ham som en populær afhandling, andre finder han for abstrakte, formalistiske, dogmatiske eller ortodokse, og om en prædiken hedder det, at den var rigere på ord end på tanker. Det begrædelige eller sødladne og - fremfor alt — "Kanzelton" (prædiketone) byder ham imod.

Men man mærker, at han føler for sine præster. Ligger deres evner på det jævne, kan han dog ofte finde noget positivt at fremhæve, som god vilje, trofasthed i gerningen, hjertelighed, mildhed eller godt forhold til befolkningen. Han er medfølende, hvor han møder rørende økonomisk nød, og overbærende, hvor han møder åndelig fattigdom.

Der kan være tilfælde, hvor han ikke kan vise skånsomhed. En prædiken får det sørgelige skudsmål: den indeholdt intet $\mathbf{i}$ strid med troen, og den prædikede dog ikke troen; hele teksten blev draget med ind, og dog blev teksten ikke behandlet. Prædikenen var helt igennem overfladisk og udvendig. Præsten har den gode vilje til at prædike evangeliet, og han mener, han prædiker det. Men han mangler desværre enhver forståelse af evangeliet. Om en anden prædiken hedder det kort og fyndigt: »hin und her, kreutz und quer, ohne Form und ohne Inhalt ". En prest kaldes rent ud en stymper uden gejstlig og kirkelig interesse og uden ret alvor. 
Endelig er der tragiske præsteskæbner, hvor Godt må optræde som den undertiden strenge, men altid medfølende sjælesørger.

Som kirkemand er Godt mest af alt præget af det, han kalder sin slesvigske "Conservatismus $"{ }^{28}$ Den belyses ved en prædiken, han har givet titlen: "Unsere Christenlosung - unsere Synodallosung! « ${ }^{20}$

Man var i 1880 nået til ende med opbygningen af en kirkeforfatning for hertugdømmerne. Der var skabt råd, bestående af lægfolk og gejstlige, først i menighederne: kirkekollegier og kirkeforstanderskab (de såkaldte menighedsældste), så provstisynoder, og nu blev endelig kronen på værket, fællessynoden for den slesvig-holstenske Landeskirche, ábnet 1880 i Rendsborg. Godt prædikede ved den lejlighed. Det var ham selvfølgelig magtpåliggende at fastlægge retningslinjerne for denne nye institution. Man kan derfor betragte hans prædiken som en slags programerklæring. Han taler om de mangler i kirken, som man i kærlighed skal søge at bøde på. Men så tilføjer han, at man i kærlighed også skal huske på det gode og sande $\mathbf{i}$ vore bestående kirkelige anordninger og indretninger, sæder og skikke, og lægge sig på sinde alt det fra vore forfædre nedarvede gamle, ærværdige og prøvede, der ikke blot skal tåles og skånes, men også værnes og plejes, for at den gamle velsignelse kan blive ny, og ny velsignelse kan blomstre for os og for vore børn efter os.

August Twestens og Claus Harms' gamle fyndord: »Wer die Religiosität der Väter will, muss auch die Religion der Väter wollen", kan stå som motto for Godts kirkelige arbejde.

Hans glæde er derfor stor, når han møder gammel kirkelighed og fromhed i menighederne, som f. eks. i Humtrup, hvor menigheden hænger bevidst ved fædrenes tro, eller i Bedsted med dens kirkelighed, velgørenhed og fredskærlighed. Der er dér ganske vist udpræget forskel $i$ politisk indstilling, men det har ingen indflydelse på den kirkelige stillingtagen, f. eks. ved de kirkelige valg; overfor alt nyt er man blevet ved det gode gamle og er vokset $\mathrm{i}$ dette.

Gammel kirkelighed må bygge på bibelen, det står fast for Godt. Han omtaler derfor med særlig glæde, at man i Skærbæk i 1873 indførte den skik at uddele gratis bibler til de nykonfir- 
merede, og særlig glad var han over, at man bad ham indlede denne nye skik ved at foretage den første uddeling. Han fandt både børnenes og forældrenes optræden ved denne lejlighed virkelig rørende og holdt en lille tale over bibelordet: Jeg har ingen større glæde end denne, at jeg hører, at mine børn vandre i sandheden (3. Joh., 4). Senere, i 1875, kunne han glæde sig over, at en lignende uddeling af bibler fandt sted i Svenstrup.

Med sin bibeltroskab lagde han megen vægt på, at præsternes prædiken var »textgemäss", tro mod dagens bibelske tekst, og særlig tilfreds var han, når han mærkede, at der lá et grundigt studium af teksten, et retskaffent tankearbejde, til grund for prædikenen. Den dansksindede Aug. H. Johannsen i Fole, en af de få præster, der skrev sin indberetning til biskoppen på dansk, var Godt således særlig tilfreds med, fordi hans prædiken hvilede på et dygtigt tekststudium og indgående forståelse af teksten. "En af de mere dannede af de danskuddannede teologer «, kalder biskoppen ham.

Gammel kirkelighed kræver ikke blot bibeltroskab, men også bekendelsestroskab. Godt var her på linje med "Kieler Blätter" og med Claus Harms. Han mâtte sammen med sin kollega i Holsten, W. H. Koopmann, tage en tørn for at værne om den slesvigske og den holstenske kirkes lutherske bekendelsestroskab.

I Preussen var den lutherske og den calvinske kirkeafdeling i 1817 blevet forenet $\mathrm{i}$ den såkaldte unionskirke. Bekendelsestro præster fandt, at man dermed svigtede sin kirkes lutherske bekendelse. Claus Harms angreb unionstanken i sine theser: Fuldbyrd ikke denne handling hen over Luthers ben. Han vil blive levende derved, og så - ve Jer!

Da hertugdømmerne nu i 1867 blev indlenmet i Preussen, var der stor nervøsitet for, at hertugdømmernes kirke skulle blive indlemmet i unionskirken. Man skulle så bl. a. have nadverfællesskab med calvinister, der har en ganske anden opfattelse af nadveren, end lutheranerne har. De lutherske præster spurgte sig selv, om de som gode lutheranere kunne tage en calvinist til alters - hver tænker jo sit derved. Og de spurgte, om en luthersk opdraget slesviger, der ligger som soldat i Berlin, kunne gå til alters hos en calvinsk præst - hver tænker jo sit derved. Og i 
menighederne talte man om, at man ikke blot skulle påtvinges et nyt styre, men også en ny religion.

Der var egentlig ikke grund til panikstemning. Bismarck havde den 30. juni 1866 sagt til Lauenborgs superintendent, at Preussen ved, hvad det har at takke agtelsen for den kirkelige bekendelse for, og at for én under andre omstændigheder opstået forenings skyld ville man ikke forstyrre freden. ${ }^{30}$

Endvidere havde de to biskopper for Slesvig og Holsten henvendt sig til den preussiske konge, Vilhelm 1., med en bøn om beroligende ord $\mathrm{m}$. h. t. unionen. De havde gennem kultusminister v. Mühler fået det svar, at kirken i hertugdømmerne skulle beholde sin bekendelse uanfægtet, som den var overleveret fra fædrene. Og siden havde de den 18. marts 1867 haft en samtale med kongen, der i varme ord erklærede, at intet lå ham så meget på sinde som det, at den religiøse tro i folket - også ved tilstedeværelsen af konfessionelle forskelligheder - blev plejet med oprigtighed og samvittighedsfuldhed. ${ }^{31}$

Endelig blev det den 3. oktober 1867 of ficielt meddelt, ${ }^{32}$ at kongen, for Slesvig og Holsten såvel som for de øvrige nye landsdele, fra begyndelsen havde udtalt den grundsætning, at en tilslutning til den i Preussen bestående union ikke kunne finde sted uden ved fri selvstændig beslutning af de dertil berettigede organer. Der var nu oprettet et evangelisk-luthersk konsistorium for Slesvig-Holsten, og det måtte være dettes opgave at få oprettet presbyterier og synoder, som så skulle bane vejen for den videre udvikling.

Men blot det spørgsmål, hvorledes landskirken skulle styres, indtil en endelig ordning blev truffet, gav anledning til livlig debat. Man kunne ønske sig som midlertidig ordning, at kirken blev lagt ind under kultusministeriet i Berlin som øverste myndighed. Det var et rent statsligt organ. Der ville altså dermed ikke være foregrebet nogen konfessionel stillingtagen. Man kunne også tænke sig kirkerådet i Berlin som øverste styrelse. Men da kirkerådet var unionskirkens overstyrelse, kunne der deri ligge en antydning af unionsvenlig kurs. Mod denne losning advarede derfor Godt på en kirkekonference i Neustadt den 25. juli 1867. ${ }^{\text {s3 }}$

Hvor jeg går, og hvor jeg står, ligger mit Slesvig mig på hjerte, erklærer han. Han havde lige været på en uofficiel visitatsrejse $i$ det provsti, der indtil Wienerfreden endnu stod under biskoppen 
i Ribe (det må være Tørninglen provsti). Mangen glæde var blevet ham til del, men hans hjerte blev også opfyldt "von grossem Weh und schwerer Besorgniss". Der var sket mange personaleforandringer. Man havde søgt at afspærre de nye gejstlige fra samkvem med menighederne. En dobbelt klage havde man rejst imod dem: de ville prædike på tysk og prædike en ny kættersk lære. Han havde ikke hørt nogen klage over de nye gejstliges danske sprog, og ofte havde han hørt den ytring: det er netop den gamle rette lære, der bliver prædiket for os. Og Godt fortsatte: slesvigeren, og særlig nordslesvigeren, har en frygt for det nye og kærlighed til det gamle ... slesvigeren er ængstelig og ømfindtlig, særlig hvor det drejer sig om troen. Man frygter, at den gamle tro skal blive afskaffet og en ny tro indført. Man frygter unionen. Jeg er overbevist om, at en brandfakkel ville blive kastet ind i samvittighederne, om man blot så meget som vakte skygge af mistanke om, at man ville deres tro til livs ... Der er allerede taget så meget fra slesvigerne, det ene efter det andet er revet fra dem. Jeg beder om, at der til alle de øvrige kampe ikke også bliver føjet kampen om troen.

Godt var således en tro discipel af Harms i sin stilling til unionskirken. Og som Harms stod han trofast på de lutherske bekendelsesskrifters grund. Det var ham derfor en særlig glæde ved visitatsen $\mathrm{i}$ Øster Lindet den 25. juni 1880, at præsten, F. E. Vogel, som han skriver, lod denne subeldag " komme til sin ret - det var nemlig henholdsvis 350 og 300 års-dagen for de førnævnte to bekendelsesskrifter, den augsburgske bekendelse og konkordiebogen.

Ja, hans glæde over at møde gammel kærnefuld lutherdom fik ham til at bære over med den gamle pastor Anders Ørbech i Arrild. Ørbech var ellers det sorte får blandt egnens præster, fordi han foretog mange kirkelige handlinger, som nabopræsterne $i$ deres lovlydighed ikke turde foretage. (Det var Ørbech, der viede Skrumsager til Kloppenborgs datter efter den berømte bortførelse).$^{3 a_{2}}$ Men Godt har dog nogle rosende ord, fordi denne gamle, underlige mand på sin ejendommelige, barokke måde dog prædiker Kristus og har gjort det lige siden sin ungdom. Folk lytter til ham, har vænnet sig til ham, kirkegangen er god, og skønt salmebogen er den rationalistiske evangelisk-kristelige salmebog, 
kan børnene mange gode gamle kærnesalmer, ligesom de er fortrolige med skriften og kan deres katekismus. Nå ja, så er der ingen dansk agitation $i$ den ellers overvejende dansksindede menighed, fordi Ørbech er en modstander deraf, og han er, som Godt skriver, en mand, der holder på autoritet og subordination "nachuntenhin " - overfor sine underordnede. Det var altså ikke nogen ubetinget ros til præsten for menighedens rolige nationale holdning.

Som bekendelsestro havde Godt selvfølgelig ikke noget tilovers for rationalistiske prædikener. De får altid en hård medfart $i$ hans optegnelser.

I 1875 konstaterer Godt med tilfredshed, at i Nørre Herred på Als, hvor rationalismen længe har behersket prædikestolene, vågner og styrkes det kirkelige og kristelige liv mere og mere. Men han er ikke tilfreds med tilstanden i Egen sogn, hvor den kendte Jørgen Hansen, ${ }^{34}$ der havde været biskop over Als og Erø 1849-64, er præst. Godt finder, at han hælder til den vulgære rationalisme og mindre er en teologisk end en advokatnatur og ikke er nogen ret sjælesørger. Hans prædiken, hedder det $i$ indberetningen, lod teksten ude af betragtning, indeholdt ikke en eneste specifik kristelig tanke, og den udviklede egentlig kun det råd at tage verden, som den er: "leben und leben lassen «. Da sognet før Jørgen Hansens 30-årige embedstid i 40 år havde haft en rationalistisk filosof som præst (Hans AhImann), må Godt beklage, at der siden 1801 kun er budt menigheden lidet.

Med bekymring betragtede Godt den ny-rationalisme, der var fremme i tiden, ${ }^{35}$ som "lysvennerne " og "Protestantenverein" $i$ Tyskland. En bevægelse af lignende karakter var fremme i Ditmarsken..$^{36}$ I Morsum på Sild havde Godt i 1881 et skarpt sammenstød i nærværelse af de kirkeældste med præsten A. F. A. Jensen, som næppe var nogen betydelig præst, men var fanget ind af lignende bevægelser. Præsten følte sig fornærmet, fordi Godt åbenbart $i$ sin katekisation og i sin tale til menigheden havde søgt at korrigere noget af det, som præsten havde sagt i strid med bekendelsen. Præsten krævede fred i kirken, d. v. s. at man skulle lade ham og ligesindede være $i$ fred og have fuld lærefrihed. Så oplyste han iøvrigt Godt om, at han kun læste blade, der var skrevet $i$ disse nye bevægelsers ånd, som "Protestantische Kirchenzeitung " 
og "Der evangelische Gemeindebote" — det sidstnævnte blad kom en tid som gratis tillæg til "Tondernsche Zeitung ".

Godt var ikke alene bibeltro og bekendelsestro. Han var også kirketro $\mathrm{i}$ den forstand, at $\mathrm{i}$ hans øjne havde det religiøse liv sin plads indenfor kirkens afstukne rammer. Denne sag har to sider.

Det betyder for det første, at lægfolket bør holde sig til sin kirke og til sin præst. Claus Harms så en fare i Wicherns virksomhed for Indre Mission i Tyskland, ${ }^{87}$ og Godt så som Claus Harms med skepsis på det, vi i Danmark kalder gudelige forsamlinger, konventikler, som han kalder det. Hvad han frygtede, var selvfølgelig, at de skulle blive arnesteder for noget sekterisk. Alt $i$ alt har det sikkert været idealet for ham, hvad han skriver om Medelby sogn, at der ikke havde været konventikler eller sekteriske bestræbelser i de 31 år, Christiansen ${ }^{37 a}$ havde været præst der. Det var en anerkendelse, at det kunne siges om præsten, at han havde formået at tilfredsstille befolkningens religiøse behov.

På den anden side var Godt ikke mere kategorisk, end at han kunne anerkende værdien af religiøse sammenkomster $i$ husene, hvis de fremmede troslivet på en sund måde. I St. Laurentius menighed på Før blev der holdt konventikler. Men Godt tog klart afstand fra den kritik, som øens præster rettede mod forsamlingerne: Guds ord bor rigeligt i husene, og mange samler sig i små kredse om ordet. Måske er der noget pietisme og "Frömmelei " med deri. Men i det store og hele hersker der sund fromhed og sand gudsfrygt, der også giver sig tilkende $\mathrm{i}$ befolkningens vandel.

Men for det andet betyder Godts kirketroskab, at præsterne skulle holde sig til deres egne kirker og menigheder. Derfor så han med bekymring på den missionsbevæegelse, som var begyndt i Nordslesvig efter 1864, og som førte til oprettelsen af "Kirkelig Forening til Guds Riges Fremme i Slesvig" ved et møde i Vojens $i$ august 1868 . Det begyndte med, at nogle præster, Neergaard ${ }^{38} i$ Aller, Michaelsen ${ }^{39}$ i Bjolderup, Grove-Rasmussen ${ }^{40}$ i Fole og Lawaetz ${ }^{41}$ i Skrydstrup, rejste rundt $i$ sognene og holdt møder $i$ kirkerne eller i fri luft. Godt skriver, ${ }^{42}$ at de betragtede sig som "pastores in partibus " — det er et gammelt udtryk, der bruges om gejstlige, der virker blandt hedninger og ikke har noget fast afgrænset virkefelt. Det foregik ganske vist loyalt efter forskrifterne, idet de forud indhentede tilladelse til deres missionsguds- 
tjenester både hos biskoppen og hos de præster, $\mathbf{i}$ hvis kirker de prædikede. Men Godt, der selv overværede nogle af disse gudstjenester, syntes, at det mindre var missions- end vækkelsesgudstjenester, at de let kunne fremkalde en slags "Nervenreiz", og at de kunne medføre, at den sædvanlige gudstjeneste i nogles øjne kunne miste $i$ værdi. Det religiøse liv burde efter hans mening først og fremmest plejes indenfor sognemenighedens rammer.

Flere præster så skævt til disse gudstjenester, og de bebrejdede biskoppen, at han tillod dem. Men Godt ville ikke direkte lægge dem hindringer i vejen. Han var bange for, at hvis man gik alt for højkirkeligt til værks, ville det føre til åbenlyst antikirkelige og separatistiske bevægelser i stor målestok - altså til yderligere opløsning af kirkens rammer. Han håbede, at når han viste disse nidkære missionspræster velvilje og tillid, så ville de også agte på hans formaninger og lære at vurdere deres embede højere og erkende det usunde $\mathrm{i}$ deres bestræbelser.

Han så da også til sin tilfredshed, at bevægelsen døde hen. Neergaard blev før sin død i 1867, som Godt skriver, mere nøgtern, og af det øvrige triumvirat slog Michaelsen ind på mere kirkelige baner, Grove-Rasmussen fik sin afsked i 1870, da han ikke ville bede for tysk sejr, og Lawaetz blev forflyttet til Sottrup.

Men Godt var - som med hensyn til konventiklerne - ikke principrytter. Han stillede sig ikke absolut afvisende overfor præsters udensogns virksomhed. Michaelsen og Lawaetz virkede stadig en del udenfor deres sogne, men - skriver Godt — på en sådan måde, at det kun kan være betænkeligt for død kirkelighed og for en fuldstændig overspændt betragtning af embedsbegrebet. Han kunne glæde sig over, at Emil Claussen i Dybbøl sammen med nabopræster holdt friluftsmøder om sommeren, som han kunne glæde sig over, at hans gode ven, Nic. C. Nielsen i Højrup, virkede langt ud over sin menighed.

Var Godt betænkelig ved de pietistiske Indre-Missions-præsters udensogns virksomhed, så forsonede han sig dog dermed. Langt alvorligere så han på den grundtvigske bevægelse.

De pietistisk indstillede præster søgte henover nationale skel at arbejde for Guds riges sag. I de grundtvigske kredse derimod var det kristelige og det folkeligt-nationale så nært forbundet, at den grundtvigske bevægelse ifølge sit væsen måtte få nationalt 
fortegn. Her kunne der ikke være tale om et kristeligt arbejde henover nationale skel.

Allerede $i$ den danske sprogpolitik mellem 1850 og 1864, der virkede så udfordrende på de fordrevne slesvig-holstenske præster, deriblandt Godt, havde der været et indslag af national grundtvigsk tankegang. Nogle af de danske præster, der kom til Mellemslesvig i den tid, arbejdede ud fra den tankegang, at kun modersmålet kunne vække det slesvigske folk af dvale. Og nu efter 1864 lød det udfordrende fra dansk side: De tyske har en anden kristendom end de danske, og tysksindede præster kan umuligt udbrede dansk kristendom og fremme dansk fromhed. Ordene faldt ved et grundtvigsk møde i Mjolden Færgegård i foråret 1869. Det var den tidligere, nu afskedigede, præst i Rødding, Hans Sveistrup, der sagde således i sit »berygtede foredrag om dansk og tysk kristendom ", som Godt kalder det. ${ }^{43}$ Det nationale var gjort til en faktor, der kunne true med at spalte den slesvigske kirke og sprænge de gamle sognerammer.

Også på anden måde rummede Grundtvigianismen en fare $i$ denne retning. Grundtvig stillede krav om ret for lægfolket til at løse sognebånd, til at søge en anden kirke og en anden præst, hvis de ikke fik deres religiøse behov tilfredsstillet i deres egen menighed. Deri måtte Godt se vejen åbnet for de gamle sognemenigheders opløsning. Sognebåndet, »Parochialnexus «, var for ham et helligt begreb. Ikke underligt, at han $i$ sine indberetninger placerede sin omtale af de grundtvigske forsamlinger under rubrikken: sekter. Han kalder et sted disse forsamlinger for »ecclesiola in ecclesia ", småkirker indenfor kirken.

Endnu en side af Grundtvigianismen måtte byde biskoppen imod. For ham var - som nævnt - de gamle lutherske bekendelsesskrifter kirkens grundvold. Grundtvig derimod så gerne indført præstefrihed, præsterne skulle ikke være forpligtet til at lære i overensstemmelse med den augsburgske trosbekendelse eller andre læreskrifter. Det var i Godts øjne det samme krav, som de gamle rationalister havde stillet, og som hans teologiske lærere havde vendt sig imod. Og det var det samme krav, som han nu mødte hos ny-rationalisterne f. eks. i Ejderstedt eller hos præsten i Morsum, og som vakte hans bekymring. Om han ligefrem betragtede de grundtvigske som rationalister, får stå hen. Hans 
lærefader, Claus Harms, synes at have gjort det. Han mente, der for en stor del blev prædiket rationalistisk i Mellemslesvig under sprogreskripterne. ${ }^{4}$

Selv om den rent nationale faktor lades ude af betragtning, måtte Godt ifølge sin teologiske indstilling vende sig mod Grundtvigianismen, fordi den kunne true med at opløse den slesvigske kirke, hvis enhed var ham en hjertesag.

Den grundtvigske bevægelse var særlig stærk i de gamle enklavesogne mod vest og i Tørninglen, altså i de områder, der indtil 1864 havde hørt under Ribe stift. I Tørninglen måtte han i 1870 afbryde sin påbegyndte visitats på grund af den "Aufregung «, som den fransk-tyske krig forårsagede. Han kunne først fortsætte visitatsen i 1871. Men medens han ellers visiterede et provsti samlet hvert tredje år, blev han nu ved med at fordele visitatsen $i$ Tørninglen provsti over to år. Han ville nemlig gerne to gange $i$ løbet af hvert tre-år besøge dette provsti, der - som han skriver - vedvarende frembød alle slags særlige vanskeligheder. ${ }^{45}$ Det var der, de omtalte ecclesiola særlig trivedes.

En sådan dansksindet grundtvigsk særkirkedannelse frygtede biskoppen - ikke uden grund - i Gram, hvor A. C. L. GroveRasmussen, der i 1870 af nationale grunde var blevet afskediget fra sit embede i Fole, havde slået sig ned og holdt møder i et lokale $i$ sit hus, der var blevet indrettet dertil. Det var netop Grove-Rasmussens tanke at danne en frimenighed i Nordslesvig ${ }^{40}$ - altså hvad Godt ud fra sit teologiske syn afskyede. Grove-Rasmussen skulle som viet præst betjene denne frimenighed med sakramenterne, medens lægprædikanter skulle varetage forkyndelsen.

Godt omtaler i 1871 disse forsamlinger i "salen", der var udstyret med en $»$ Rednerstuhl . Og han skriver videre, at jo mere Grove-Rasmussen $i$ den sidste tid har vendt sig $i$ retning af Grundtvigianismen, jo mere nødvendigt må det være at skaffe en dygtig medhjælper for den 72-årige sognepræst, R. A. Rafn. (Grove-Rasmussen havde været kapellan hos Rafn 1864-68). De kirkeældste har onsket at beholde Rafn. Godt har ikke turdet spørge dem, om de ønskede dette med henblik på den virksombed. som man ventede sig af Grove-Rasmussen. Men han anser dette for så meget mere muligt, som de ellers ikke har lagt skjul på deres afgjort danske sindelag. 
Af økonomiske grunde måtte imidlertid Grove-Rasmussen give op i Gram. Han blev 1874 prest i Harte og håbede så derfra at kunne udstrække sin virksomhed til Nordslesvig. Men samme år blev det forbudt udenlandske, $d$. v. s. danske præster at virke $i$ Sønderjylland. Vejen var spærret for ham til den påtænkte frimenighedsdannelse. Og samme år oplyser Godt, at Rafn har fået en medhjælper, samt at Grundtvigianismen og lignende bestræhelser ikke har fundet indgang i Gram.

Det kunne biskoppen jo forsåvidt være godt tilfreds med. Værre gik det imidlertid i Rødding.

Den før omtalte Hans Sveistrup ${ }^{47}$ der i sine unge år var blevet betaget af en af Grundtvigianismens profeter, præsten Vilh. Birkedal, havde været præst i Rødding, men blev afskediget i 1867 på grund af edsnægtelse. Han fortsatte dog med at holde gudstjenester på højskolen i Rødding, hvor han - som Godt skriver - anrettede "allerlei Verwirrung". 1870 fik han embede i Vejen, og derfra berejste han Nordslesvig og holdt møder og forsamlinger. Han holdt også regelmæssige gudstjenester i Rødding.

Imidlertid blev det, som sagt, i 1874 forbudt danske præster, altså også Sveistrup, at virke i Slesvig. Det førte til, at Cornelius Áppel, der i 1864 var blevet afsat som lærer i Tønder og nu drev højskolen i Rødding, fortsatte de påbegyndte gudstjenester. Og hvad der særlig chokerede: i 1874 lod han sig - i strid med dansk lovgivning - ordinere i Askov af Vilh. Birkedal, bl. a. bistået af Sveistrup. ${ }^{48}$ Dermed var den første danske frimenighed $i$ Nordslesvig skabt. ${ }^{48}$ Godt beretter, at den "ordnungswidrig " i Danmark ordinerede seminarist Appel holder hver søndag, skiftevis i Rødding og i Skrave, om eftermiddagen kl. 4 »unter polizeilicher Aufsicht " gudstjenestelige forsamlinger og forretter for sine tilhængere, der er udtrådt af den lutherske kirke, 25 i Rødding og 15 i Skrave, præstelige funktioner. Godt vil vide, at i Københoved har den religiøse spaltning stiftet megen ufred, og splittelsen og fjendskabet beklages smerteligt af mange.

Det var værre end i Gram. Grove-Rasmussen var dog præsteviet på lovformelig vis, og han var vel næppe så stejl en natur som Appel. Men nu var altså den første frimenighed en realitet med deraf følgende bitter partimodsætning. En sognemenighed var slået i stykker. Og menighedens sjælehyrde øvede præstelige funktioner, skønt han var lægmand og var ordineret på lovstridig vis. 
En trøst fandt Godt dog deri, at det skete havde virket frastødende på mange af dem, der hørte til landskirken. "Nu bliver det alt for galt", hed det sig (Godt citerer udtalelsen på dansk). Mange blev, mente biskoppen, ved de »grundtvigianische Triebe bestyrket $i$ deres værdsættelse af kirken.

Den næste frimenighed blev dannet i Bovlund i Agerskov sogn, hvor Appels tidligere elev på seminariet i Tønder, L. B. Poulsen, slog sig ned og holdt grundtvigske forsamlinger - sognet var grundtvigsk påvirket af den tidligere præst, biskop Boesens broder, G. F. Boesen, med hvem Poulsen tidligere som lærer i Rangstrup havde haft samarbejde. Boesen holdt stadig i 1870 forbindelsen vedlige med de grundtvigske $i$ sognet, der gav præsten "Viel zu schaffen". Forsamlingerne blev "polizeilich genau überwacht «. I 1879 lod Poulsen sig præstevie af Appel. Den anden frimenighed var dannet. Atter et spaltet sogn og atter en lægmand som præst - endda præsteviet af en lægmand.

I det stærkt grundtvigsk påvirkede sogn Mjolden var Sveistrups møder ophørt efter forbuddet $1874 \mathrm{mod}$ danske præster. Desuden havde man fået den meget betydelige pastor Hans Schlaikier Prahl til sognet. Godt mente derfor, at der var udsigt til, at det dér skulle mislykkes at få dannet frimenighed, således som det tilstræbtes af "fremmede agitatorer , og at sektvæsenet så ved Guds hjælp ville forsvinde. Hans håb blev i nogei. grad skuffet. 1881 beretter han, at Poulsen hver 14. dag $i$ en "Bude" i Forballum holder gudstjeneste for s separatisterne". Det blev spiren til den senere frimenighed i Skærbæk, der dog først blev dannet i 1899, altså længe efter Godts død.

Iøvrigt noterer Godt sig selvfølgelig overalt de steder, hvor der holdes grundtvigske forsamlinger. I sine seneste visitatser fik han det indtryk, at der var en vis stilstand $\mathbf{i}$ den grundtvigske bevægelse. Det er sandsynligt, at hans indtryk er rigtigt. Ophævelsen af $\S 5$ kan have virket lammende. Fra Vilstrup sogn beretter Godt i 1880 , at efter ophævelsen af $\$ 5$ er der nogle af dem, der hidtil af politiske grunde har holdt sig borte fra kirken, der atter tager del i gudsijenesten.

Sin uvilje mod Grundtvigianismen skjuler han ikke. To privatlærere i Hvidding får det skudsmål, at de er begge grundtvigske og foragter vel principielt positiv viden. ${ }^{50}$ Roskilde konvents salmebog betragter han som "grundtvigianisch" og sætter sig flere ste- 
der mod dens indførelse. ${ }^{51}$ En lærer fik forkastet et forslag til en skolesalmebog, fordi den ensidigt repræsenterede »den glade Christendom " (udtrykket er anført på dansk).$^{52}$

I de visitatsberetninger, der ligger til grund for nærværende fremstilling, møder man først og fremmest Godt som en kirkens mand, der bedømmer sine præster efter, hvad de kirkeligt formâr at udrette, og særlig efter, om de formår at samle deres menighed om forkyndelsen, så ingen skiller sig ud og søger deres religiøse behov tilfredsstillet i konventikler, sekter eller udensogns forsamlinger.

I denne henseende havde Claus Harms givet præsterne et godt råd $i$ sin $\gg$ Pastoralteologi ${ }^{53}$ : Hvis der danner sig konventikler $i$ menigheden, skal de holde en offentlig gudstjeneste mere og gøre deres prædikener bedre. Så kunne de måske tilfredsstille dem, der søger opbyggelse udenfor kirken, så de ikke behøvede at gøre dette mere. "Immer zuerst in uns selbst gehen « lyder hans formaning.

Dette "immer zuerst in uns selbst gehen" var for Godt, hvad præsterne skulle holde sig til, når nogle - som netop de grundtvigske - skilte sig ud fra præst og menighed. Det var forst og fremmest præsten, der måtte bære ansvaret for sin menighed.

Christiansen i Medelby, der i 31 år havde gjort konventikler og sekter overflødige $i$ sin menighed, var ham et eksempel på, at en dygtig præst formår at holde sammen på en menighed. For at prøve at holde sammen på det stærkt grundtvigske Mjolden sogn fik han den fremragende dygtige præst Hans Schlaikier Prahl anbragt dér. Prahl gjorde da også et meget energisk arbejde på at fremme kirkelivet, bl. a. ved at knytte til sognets grundtvigske traditioner. ${ }^{84}$

Kunne en præst derimod ikke holde sammen på sin menighed, og gav han grundtvigsk eller national opposition skylden, kunne det meget vel ske, at Godt tog den danske menigheds parti overfor den tyske præst.

Hermann Roll i Hjerting fnyste over indflydelsen fra den nærliggende Rødding Højskole, idet dens politiske proselytmageri virkede opløsende på hans menighed. Men Godt indberetter herimod, at selv om Roll er en agtværdig og ikke udygtig mand, skulle han ikke have været præst og særlig ikke i en landmenighed. Derimod viser biskoppen menigheden udelt sympati. Den mangler ikke kir- 
kelig sans, og den viste ved visitatsgudstjenesten "eine fast wunderbare Stille und Aufmerksamkeit «. Det var hverken Appel eller Rødding, der fik skylden.

N. C. Schmidt i St. Laurentius på Før havde ikke noget godt forhold til menigheden. Nabopræsterne mente, det skyldtes menighedens fanatiske dansksindethed. Det var gammelt enklavesogn, der til 1864 havde hørt under Ribe bispestol. Men biskoppen retter kritikken mod præsten, der end ikke undser sig for at bruge lånte prædikener. Han kalder derimod menigheden en af de mest kirkeligt sindede i Slesvig. Selv Schmidt har ikke kunnet prædike sdie Westerländer" ud af kirken.

Provst Göttig i Åbenrå beklager sig over det danske partivæsen og erklærer, at menigheden er ødelagt af de sidste 20 års politiske virvar: der er megen usandhed, løgn, hykleri, bedrageriskhed, uforskammethed, trods, had og vrede. Men Godt oplyser, at Göttigs virksomhed kun er ringe, hans prædikener bringer kun liden opbyggelse, og iøvrigt bebrejder man ham - også fra de tysksindedes side - hans "Nörgelei " og egenmægtighed.

Omtalen af præsternes nationale indstilling indtager i almindelighed ikke nogen fremtrædende plads. Man får ikke indtryk af, at det er noget, Godt lægger megen vægt på, hvis de kirkeligt kan udfylde deres plads.

Er de tysksindede, bør de søge at omgås befolkningen og forsone og vinde deres hjerter. ${ }^{\text {ss }}$ Optræder de udfordrende, får de kritik. Godt var ikke tilfreds med, at pastor Riis i Rejsby uden at have fået befaling dertil bad for tysk sejr i 1870, skønt menigheden havde opfordret ham til at lade være med det. Pastor Stapel i Brøns holdt i 1873 en prædiken over bibelordet: "Lader os ikke forlade vor egen forsamling, som nogle har for skik " (Hebr. 10, 22-25). Han hentydede dermed til nogle af menigheden, der forlod sognemenighedens forsamling og $\mathbf{i}$ den nu nedlagte højskole i Brøns gik til gudstjenester, hvor bl. a. Sveistrup prædikede. Skønt Godt såvist hverken yndede Sveistrup eller grundtvigske forsamlinger, gav han dog Stapel en irettesættelse for denne prædiken, som han karakteriserer som helt igennem spydig og sårende.

Er præsterne dansksindede, som f. eks. Chr. Schwensen i Hørup, der sskønt født i Slesvig er ivrig dansksindet ", tager han det til efterretning, blot de ikke træder frem dermed, forholder sig politisk passive og ikke gør sig skyldige i noget. Præsten i Dybbøl, 
hvortil grev Reventlow på Sandbjerg havde patronatsret, var den dansksindede, kirkeligt meget virksomme Emil Claussen, søn af vajsenshus- og seminarielærer i Tønder, Hans Claussen. Om pastor Claussen skriver Godt: at hans politiske holdning i nogles øjne er mistænkelig, ved jeg, men jeg ved ikke, at der foreligger nogen grund dertil. Om tidligere biskop Jørgen Hansen i Egen hedder det: Han bliver almindelig anset for en hovedstøtte for danskheden på Als, og var engang en af de af kongen af Danmark til regering for Slesvig udnævnte triumvirer. ${ }^{56}$ Det er imidlertid aldrig siden 1864 blevet påvist om ham, at han har agiteret politisk, og det er en kendsgerning, at han har været utilfreds med mange af de forholdsregler, som blev truffet af ministeriet for hertugdømmet Slesvig. Med stor sympati omtaler Godt den dansksindede pastor Johannsen i Fole. Om den 72-årige dansksindede pastor Rafn i Rødding skriver han, at hans varme og inderlige prædiken minder ham om biskop Mynsters betragtninger.

Dygtige præster, som bevidst sætter det kristelige over det politiske, giver Godt udelt anerkendelse for deres kirkelige arbejde, som f. eks. Christiansen i Medelby, Lawaetz i Skrydstrup, siden i Sottrup, og Nic. C. Nielsen i Højrup.

I sogne, der trues med splittelse til skade for kirkelivet, møder man bevidst forsøg på at modvirke de opløsende tendenser ved ansættelse af dygtige præster, som Prahl i Mjolden eller Kaftan og Tonnesen i Ảbenrå. I Hammelev havde man som præst ønsket den tidligere missionær Grönning, ${ }^{37}$ der som konstitueret andenpræst i Åbenrå 1868-73 havde haft de danske gudstjenester med god tilslutning, ikke blot af de dansksindede. Men Godt fik ansat den pietistiske Obbarius, som han kalder: ret en præst for politisk indstillede vakte. Menigheden takkede biskoppen for denne udnævnelse, hvad man også andre steder møder eksempler på.

Hovedindtrykket af det her benyttede materiale er det, at biskop Godt har fulgt kirkelige og teologiske retningslinjer, som har deres udspring hos hans teologiske lærere, ikke mindst Claus Harms.

Hans mål var sund fromhed og sand gudsfrygt, ${ }^{58}$ på bibelsk grund, i troskab mod gammel luthersk bekendelse og med respekt 
for den slesvigske kirkes gamle sognekirkelige rammer og de fra forfædrene nedarvede sæder og skikke.

Hans krav til præsterne var, at de skulle undgå politisk og hierarkisk væsen og arbejde med selvfornægtende kærlighed og hengivelse.$^{59}$ De skulle ved deres forkyndelse og hele virksomhed knytte menighedernes medlemmer således til deres prast og deres kirke, at ingen behøvede at søge uden for de sognekirkelige rammer for at få deres religiøse behov tilfredsstillet. De skulle således værne kirken mod alle opløsende tendenser, hvadenten disse var af national eller sekterisk karakter.

Dette er altsammen rent teologiske og kirkelige synspunkter. Man får ganske umiddelbart det indtryk, at Godt havde sit bestemte teologiske og kirkelige standpunkt, og at han i sin bispegerning har søgt at handle ud fra dette standpunkt og altså ikke har svigtet sin kirkelige opgave, således som han forstod den.

Så vidt det teologisk-kirkelige. Til slut et par hypotetiske bemærkninger om det politiske, der ikke er fremtrædende i visitatsberetningerne.

Godt formanede sine præster til at undgå politisk væsen, men derimod søge at forsone og vinde befolkningens hjerter. Der er intet nationalt udfordrende $i$ visitatsberetningerne. Godt kunne meget vel tage dansksindede menigheder i forsvar overfor aggressive tyske præster. Han kunne fuldtud anerkende et dygtigt arbejde af en dansksindet præst. Man har mindre indtryk af uvilje mod det danske element end af bestræbelse for at overvinde dansk mistænksomhed. Han skriver 1880 om Rødding: "alt, hvad der kommer fra syden, støder hos flertallet på mistænksomhed og er ilde anskrevet «. Denne mistanksomhed førte til, at det ofte holdt hårdt at genoplive de hensygnende kirkekatekisationer eller at vække interessen for kirkelige formål som ydre mission, bibelsagen, diakonissesagen eller Gustav-Adolf-foreningen. Man møder flere gange den oplysning om disse foretagender, at de betragtes som "eine deutsche Neuerung *.

Når Godt advarede mod politisk væsen, var det, fordi det kunne vække en mistænksomhed, der var til skade for kirkelivet.

Det gådefulde er, at Godt selv i 1864 optrådte alt andet end upolitisk. Hans optræden som provst i 1864, hans tale ved genoprettelsen af den slesvig-holstenske Gustav-Adolf-forening og 
hans berygtede påbud om en takkegudstjeneste i kirkerne for den fred, der "må opfylde os med levende glæde", var en særdeles udfordrende proklamation af hans slesvig-holstenske standpunkt. Den bekendelsestro kirkelighed, som han havde mødt i sin studietid, havde som omtalt fælles udspring med Slesvig-Holstenismen i kredsen omkring "Kieler-Blätter". De unge professorer, han havde mødt ved universitetet $i$ årene fra 1834 , gled alle ind $i$ den slesvig-holstenske bevægelse. Han havde fra sine første præsteår og gennem sit ægteskab føling med hoffet på Augustenborg. I tiden mellem krigene havde han som præst i Ruhregnen delt den slesvig-holstenske gejstligheds bitterhed over det danske styre i Slesvig. Nu folte han sig stående overfor opfyldelsen af det slesvig-holstenske mål. Der var gjort ende på det danske styre, specielt de så omstridte sprogreskripter, som i den slesvig-holstenske gejstligheds øjne havde været til så stor skade for kirkelivet $i$ Slesvig.

Det var situationen i 1864 . Men siden blev situationen en anden. Godt fik ikke det selvstændige Slesvig-Holsten, som han havde set hen til med så store forventninger. Han fik et preussisk styre. Provst Zieses ord ved Godts begravelse, at Godt var betænkelig ved meget af det, der skete på politisk område, men han lærte at bøje sig for nødvendighedens jernhårde gang, kan meget vel hentyde til landets indlemmelse i Preussen. Hans slesvigske sindelag kommer måske også til udtryk i hans store sympati for Niels Schmidt i Svenstrup, der havde nedlagt sit embede ved seminariet i Tønder på grund af uvilje mod det preussiske styre.

Det kan altså meget vel tænkes, at Godt som slesviger ikke har følt sig som det nye tyske styres håndgangne mand, men at han som slesviger har følt det preussiske styre og den preussiske indflydelse som noget fremmed, som han måtte værne slesvigerne imod - måske endda også værne de dansksindede nordslesvigere imod.

Godt talte ikke mindst nordslesvigernes sag, da han værnede den slesvigske kirke mod at blive indlemmet $i$ den preussiske union. Han var ikke ukritisk overfor den preussiske lov i 1874 om tvungen borgerlig vielse. ${ }^{* 0}$ Han delte præsternes bekymring for, at denne lov skulle svække respekten for de kirkelige handlinger og således gøre befolkningen fremmed for kirken. Ganske vist kunne han med tilfredshed konstatere, at loven var upopulær 
i befolkningen. De fleste lod sig stadig kirkeligt vie - ja, i Skrydstrup kunne et udefra kommende ægtepar, der ikke var kirkeligt viet, ikke få bolig, fordi ingen ville leje til dem. Loven fik altså stort set ikke uheldige følger. Men der ligger dog en stille kritik i påvisningen af farerne ved loven og omtalen af befolkningens uvilje - og også deri, at han må notere, at loven førte til, at en del nordslesvigere brugte den som påskud til at lade sig vie i Danmark.

Intet $\mathrm{i}$ visitatsberetningerne tyder på, at Godt ønskede at germanisere Nordslesvig. Selvfølgelig var den danske sprogordning i Mellemslesvig blevet ophævet. Det var sket, før Godt blev biskop. Men det er H. P. Hanssens mening, ${ }^{61}$ at Godt værnede det danske sprog i kirke og i skole, hvor det havde været dansk før 1848, altså før sprogreskripterne. Og $\mathrm{H}$. P. Hanssen vil mene, at Godt ville have gjort energisk modstand mod den fortyskning, der fandt sted i Nordslesvigs kirker og skoler efter Godts død. Det kan iøvrigt nævnes, at i 1885 sagde Godt til en præst i Valsbøl, der havde hjemmedøbt et barn på dansk, fordi moderen ikke forstod tysk: "Tal De i religiøse spørgsmål det sprog med folk, som de bedst forstår « ${ }^{\theta 2} \mathrm{Og}$ i Ubjerg og Sønder Løgum sogne, hvor der blev holdt dansk gudstjeneste den første søndag i hver måned, forsvarede Godt denne ordning som nødvendig, skønt en del af befolkningen var imod den og ville have den afskaffet. ${ }^{\text {as }}$

Det forekommer ikke usandsynligt, at Godt som slesviger med slesvig-holstensk fortegn ganske vist, men dog som slesviger - har stået med front til to sider, både mod nord og mod syd. I Sønderborg var man ikke tilfreds med fordelingen af danske og tyske gudstjenester. Godt bad så de kirkeældste prøve at enes om et forslag, men formanede dem til kun at søge om det kirkeligt nødvendige, men holde politiske tendenser ude. ${ }^{64}$ Dette kan forstås derhen, at Godt ikke blot ville holde det politiske ude, fordi han ville søge at modvirke mistænksomheden i danske kredse, men også fordi han ville afværge mistænksomhed hos de højere tyske myndigheder - til skade for kirkelivet.

Alt dette sidste er hypoteser. Der skal mere vidtgående undersøgelser til, før problemet om Godts politiske indstilling er tilstrækkeligt belyst. Blandt andet må man vide besked om, hvilke retningslinjer han har fulgt ved embedsbesættelser. Det giver visitatsberetningerne ingen væsentlige oplysninger om. 
Tilføjelse:

Til belysning af biskop Godts forhold til den augustenborgske slægt kan oplyses:

Biskop Godts svigermoder, Charlotte Petersen, f. Hinrichsen, gift med fyrstelig hof råd på Augustenborg Joachim Petersen, stod i nært venskab til Christian 8.'s dronning, Caroline Amalie, idet de i deres barndom var opdraget sammen på Augustenborg. Caroline Amalie var datter af Frederik Christian af Augustenborg og søster til Christian August af Augustenborg og Frederik af Nør.

I et brev til sin svigerinde, Christian Augusts hustru, Louise Sophie, gav dronning Caroline Amalie hende meddelelse om Godts forestående afskedigelse fra embedet i Felsted i 1850, og Louise Sophie lod meddelelsen gå videre til Charlotte Petersen.

Fra Caroline Amalie foreligger et brev til biskop Godt fra 1873 i anledning af hans hustrus dod.

(Efter oplysning fra kontreadmiral Eb. Godt, der velvilligst har stillet fotokopier af de pågældende breve til min rådighed).

\section{NOTER Og HENVISNINGER}

1. Pastor Schnittgers ligtale i hjemmet. Kirch. u. Schulblatt 1885, nr. 26.

2. Flensborg Bys Hist, II. 1955, s. 122 og: Flensburg, Geschichte einer Grenzstadt, Flensb. 1966, s. 270.

3. C. F. G. Heinrici: D. Aug. Twesten, Berlin 1889.

4. A. Springer: F. C. Dahlmann, I. 1870 , s. 84 ff. C. H. Pfaff: Lebenserinnerungen, 1854, s. 304. Jvfr. Chr. Degn i Gesch. Schleswig-Holsteins VI., s. $354 \mathrm{ff}$.

5. Cl. Harms: Ausg. Schr. udg. af Dr. Peter Meinhold, Flensb. 1955. I., s. 261.

6. Friedrich Wintzer: Claus Harms. Flensburg, 1965. - Claus Harms' Leben in Briefen, herausg. v. Heinrich Zillen. Kiel. 1909.

7. Th. H. F. Hansen: Rede am Sarge des heil. Geheimen Oberkirchenrath und Oberhofprediger Dr. theol. Nielsen, Oldenburg, 1883.

8. C. E. Carstens: Geschichte der theologischen Facultät der Universität in Kiel. Zeitschr. f. Landeskunde V. 1874, s. 44 og 67.

9. Carstens s. 94, 115, 91, 85 .

10. E. Bruhn: Der theologische Verein zu Kiel 1836-1886, Kiel 1886.

11. Gnomon, 3' Aufl. Kiel u. å., s. $425 \mathrm{f}$.

12. Des Volks Trauer und Trost. Kiel $\mathbf{1 8 4 0 .}$

13. Ueber ein Kleines und aber ueber ein Kleines, Kiel 1848.

14. M. Mørk Hansen: Slesvigske Tilstande og Stemninger . 1864. Kbh. 1865 , s. 82 ff.

15. Ernst Michelsen: Der Gustav-Adolfs- Verein in Schleswig-Holstein. Kiel. 1893. 
16. B. Godt: Predigt am 13. Juli 1864 bei der Hauptversammlung des Schleswig-Holst. Hauptvereins der Gustav-Adolf-Stiftung zu Schleswig. Kiel. 1864.

17. Schriften d. Ver. f. Schl-Holst. Kirchengeschichte. 2. Reihe, VI. 1917. 551. - Meddelelser om Begivenhederne i Slesvig. Jan. 1865, s. 93.

18. Kirchen- u. Schulblatt, 1885, nr. 27.

19. Briefwechsel zwischen H. L. Martensen und I. A. Dorner, 1888, s. 223.

20. Carsten Petersen: Slesvigske Præster 1938, s. 171.

21. Jens Holdt i Kirkehist. Saml. 7. rk. VI, 1967, s. 453.

22. $31 / 51737,14 / 121739$ jvfr. 5/5 1749. Syst. Sammlung der Verordnungen f. Schlesw. u. Holst. III 1830, s. 160, 122, 162.

23. Efter gammel skik, indskærpet ved cirkulære af 1845 , skulde børnene over 12 år møde til katekisation ved gudstjenesten om søndagen og ved de særlige gudstjenester om onsdagen $\mathrm{i}$ fastetiden. Se: Chron. Samml. der Verordn. 1845, s. 154.

24. H. P. Hanssen: Et Tilbageblik, II., s. 40. - Ammundsen i Da. biogr. Leksikon.

25. Indberetn. fra Tønder provsti 1869. (Gott.)

26. E. Albeck i Tønder Statsseminarium, 1888-1938 . 1938, s. 82 f.

27. Jens Holdt: Nicolai C. Nielsen. Sdrj. Årb. 1958, s. 1 ff.

28. Kirkehist. Saml. 7. Rk. VI., s. 463.

29. B. Godt: Unsere Christenlosung - unsere Synodallosung. Schleswig 1880 .

30. Schr. des Ver. f. Schl. Holst. Kirchengesch. 2. Reihe, VI, s. 518.

31. Kirchen- u. Schulblatt 31/3 1867, nr. 13, s. 105.

32. Kirchen- u. Schulblatt 6/10 1867, nr. 40, s. 333 .

33. Kirchen- u. Schulblatt $4 / 81867$, nr. 31, s. 257.

33a. Haabets Mænd, v. H. Lausten-Thomsen og Nic. Svendsen, s. 39.

34. Se Dansk biogr. Leksikon og litteraturhenvisn. dér.

35. Kirchen- und Schulblatt 1885 , nr. 27.

36. Dr. Otto Zacharias: Der gegenwärtige Kampf zwischen Buchstabenglauben und Christentum in der schl.-holst. Landeskirche, Garding 1880.

37. Franz Schnabel: Deutsche Geschichte im neunzehnten Jahrhundert, IV, Freiburg 1951, s. 436.

37a. Holger Hjelholt: Pastor Chr. Christiansen, Medelby. Sdrj. Årb. 1926, s. 1 ff.

38. Worte der Erinnerung an Harald von Neergaard. Altona, 1867.

39. Jens Holdt: Jørgen Michaelsen, Ribe Stifts Årb. 1951, s. 52 ff. jvfr. B jolderup Sogns Historie, 1951-52, s. 318.

40. H. R. Hansen: A. C. L. Grove-Rasmussen. 1905.

41. J. Johansen: Oplevelser i Sønderjylland 1860-1871, Kbh. 1899, s. 181. - H. P. Hanssen: Et Tilbageblik, III, 287.

42. Godts indberetning om Bjolderup 1871 (Åb. provsti. Åb.)

43. Godts indberetn. fra Brede 1869 (Tønder provsti, Gott.) og fra Mjolden 1871 (Loh-Møgeltønder provsti. Gott.)

44. Cl. Harms' Leben in Briefen, herausg. v. H. Zillen, Kiel, 1909, s. 398 .

45. Godts indberetn. for Tørninglen provsti, dat. 11/2 1874. (Åb.) 
46. H. R. Hansen: A. C. L. Grove-Rasmussen. 1905, s. 22 f.

47. H. Kau: Præsten Hans Svejstrup, 1899. - H. Nutzhorn: Præsten H. Sveistrup, 1914.

48. L. Schrøder og L. Helveg: Om Corn. Appels Ordination, 1874.

49. Thade Petersen: De sønderjydske Frimenigheders Historie, 1924.

50. Hvidding 1879.

51. Døstrup 1881. Skrydstrup 1874.

52. Nybøl 1868.

53. Cl. Harms: Pastoraltheologie, 2. Aufl. 1837, III, s. $80 \mathrm{f}$.

54. Prahls indberetn., Mjolden 1874, ( $\AA \mathrm{b}$ : i pk: Tørninglen provsti.)

55. Godts indberetn. fra Rejsby 1873 .

56. Herom se: N. Neergaard: Under Junigrundloven, I. 279.

57. Chr. Wienberg: Sønderjyllands Indsats i Verdensmissionen før 1920. Kbh. 1939 , s. $50 \mathrm{ff}$.

58. Godts indberetn. fra St. Laurentius, 1875. Tønder provsti (Gott.)

59. Godts indberetn. fra Tønder provsti 1875 (Gott.)

60. Indberetn. om visitatsen i Tønder provsti 1875 , dat. $2 / 2$ 1876. (Gott.)

61. H. P. Hanssen: Et Tilbageblik II, s. 40.

62. H. Tonnesen: Nordslesvigsk Kirkeliv, 1925, II, s. 11.

63. Indberetn. fra Ubjerg 1869 og fra Sdr. Løgum 1875. (Tønder provsti. Gott.)

64. Godts indberetn., Sønderborg, 1872. (Sønderborg provsti, Ab.) 